\title{
Use of Video Clips in a Virtual Learning Environment of Accounting Information Systems Class-A Case Study
}

\author{
Baozhou Lư ${ }^{1}$, Liang Song ${ }^{2}$ \\ ${ }^{1}$ China University of Petroleum, Qingdao, China \\ ${ }^{2}$ Michigan Technological University, Houghton, USA \\ Email: fudlbz@gmail.com, liangs@mtu.edu
}

Received May 10, 2013; revised June 28, 2013; accepted July 12, 2013

Copyright (c) 2013 Baozhou Lu, Liang Song. This is an open access article distributed under the Creative Commons Attribution License, which permits unrestricted use, distribution, and reproduction in any medium, provided the original work is properly cited.

\begin{abstract}
It is more challenging for accounting students to learn and engage with the technology, used in the accounting field because of an increase in student numbers and a decline in teachers. We provide a practical knowledge of how video clips can be created and used to teach accounting information systems. Video clips of how to use Sage 50 Accounting are created by Camtasia Studio and distributed to students. The students' leaning experiences show that video clips help a lot when they study in accounting information systems class.
\end{abstract}

Keywords: Accounting Education; Technology in the Classroom; Accounting Information Systems

\section{Introduction}

It is very important for accounting students to have an excellent grasp of changing accounting software in addition to accounting theory behind it. However, it is more challenging for accounting students to learn and engage with the technology used in the accounting field because of an increase in student numbers and a decline in teachers. For example, there is little opportunity for accounting teachers to have one to one direct tuition in the use of accounting software. Some students may be less confident to ask accounting teachers to explain the procedure again and it is especially true for international students.

In this paper, we provide a practical knowledge of how video clips can be created and used to teach accounting information systems. Video clips of how to use Sage 50 Accounting are created by Camtasia Studio and distributed to students. The students' learning experiences show that video clips help a lot when they study in accounting information systems class.

\section{Literature Review}

Video clips are defined as sequence of multimedia messages that present images, narration and text at the same time [1]. The literature has documented several advantages of application of video clips in education. Specifically, video clips are important visual aids for language learners by providing settings, action, emotions and ges- tures [2]. Video clips are useful in dental education [3]. Online video clips help students to learn marketing [4].

Compared with explaining something orally, there are some advantages to employ video clips to teach accounting information systems. For example, we can explain how important the physical security is in the way of one to one supervision. But it is much better to show a video about different types of locks to safeguard assets. Although there are some advantages of utilizing video clips, there still are some disadvantages, such as the absence of personal interaction between the students and the teachers.

The application of video clips in accounting areas is summarized in the existing literature [5]. In 2010 AICPA annual national undergraduate case competition, students are required to use video clips to demonstrate their case solution. In 2011 AICPA student case competition, students are required to create and submit a video on the topic of Fraud and Forensic Accounting. In addition, more and more accounting professors are beginning to employ student video projects or assignments. For example, accounting professors in the University of Illinois assigned a student group to create three videos on "the importance of being independent," Professors of the Accounting Department at the University of Nevada, Las Vegas, supervise students to do a video project on the various employment opportunities available to accounting majors. 
It is necessary to introduce video clips into accounting information systems class because there are the operational difficulties to teach accounting information systems. The increase in student numbers and a decline in teachers make this situation even worse. For example, when the students try to learn and use accounting information systems, they have to remember several steps correctly to achieve an objective. If they can not finish one step in the right way, they cannot go ahead to finish other steps. However, the limited time in the class cannot let the teachers to meet the demand of the students to remember everything. The video clips can solve this problem because the students can watch it again and again after the class. In our paper, we try to provide a practical knowledge of how video clips can be created and used to teach accounting information systems.

\section{The Class Project}

In our accounting information systems class, we want to provide hands-on accounting software experience for students. So they can be more competitive in the job market after they graduate. To achieve this goal, we require students to finish an accounting project using the software Sage 50 Accounting, which is formerly called the Peachtree software. The reason for us to select Sage 50 Accounting is that it includes all common features and students can quickly learn another accounting software based on their knowledge in Sage 50 Accounting. Specifically, Sage 50 Accounting can "manage cash flow, customer payments, and collections; gain insight with custom reporting for budgeting, cash flow management, and benchmarking; get a high-level view of your key metrics; track inventory, plan purchases, or expand service offerings; and reduce errors and deter fraud with screen-level security and a clear audit trail". ${ }^{1}$ Another important reason is that we can get an education edition of Sage 50 Accounting for free.

To further reduce students' cost, we use a free practice set provided by Perdisco. In this project, "Students complete a one-month accounting cycle for a fictional business with all posting; journalizing and financial reporting completed using the actual Sage 50 accounting software". ${ }^{2}$ Specifically, there are seven sections, such as "reading the company's accounting policies and procedures"; "creating the company data file"; "setting up company records"; "recording transactions"; "preparing a bank reconciliation"; "recording adjusting entries" and "printing reports, creating a final backup and submitting your work". After students finish this project, our objective is to make them familiar with how to use an accoun-

\footnotetext{
${ }^{1}$ More details can be found from the website:

http://na.sage.com/sage-50-accounting-us

${ }^{2}$ More details can be found from the website:

http://www.perdisco.com/sage50/
}

ting software to implement their accounting knowledge.

\section{Video Clips as Teaching Aids}

One challenge for accounting students to learn the functions of Sage 50 Accounting is accounting teachers do not have enough time to interact with each student because more and more students enrolled in accounting information systems class. In addition, some students may be less confident to ask accounting teachers to explain the procedure again in a large group setting and more and more international students make this situation even worse. To solve this problem, we introduce video clips to our accounting information systems class and use it to record how to finish each section and distribute to students. So students can watch it after class. In addition, when we try to answer students question, we also use video clips to record the answer.

In order to make video clips, we use the software Camtasia Studio. "This software can easily record the screen, PowerPoint presentations, web camera video, and audio; edit for professional polish, enhance for emphasis; Share crystal-clear videos at any screen size...on Web pages, blogs, CDs, or portable devices like the iPod." ${ }^{3}$ In our accounting information systems class, we try to finish each section ourselves. At the same time, we record our computer screen using Camtasia Studio. So the students can see how the mouse will move on the computer screen to complete each section. For some difficult parts, we zoom in and put some emphasis on it. We also record our lecture into the video slips. Then we distribute these video clips to each student by email or our class website.

\section{The Students' Learning Experience}

Our initial finds are very positive and students have gained a lot of benefits from these teaching aides. According to interviews with the students in our accounting information system class, 76\% of students answer "Yes" to the question "Did you prefer the digital video demonstrations to the one to one supervision?" $67 \%$ of students answer "Yes" to the question "Did video clips help you best when you study accounting information systems?" $35 \%$ of students answer "Yes" to the question "Did you feel confident to use accounting information systems after this class?” which is higher compared with $25 \%$ of students answer "Yes" to the same question when video clips are not adopted.

We also get some useful comments from the students. Students indicate that they would like to use the video clips again. They also comment that video clips with less

\footnotetext{
${ }^{3}$ More details can be found from the website:

http://www.ats.ucla.edu/stat/seminars/MakingMovies/

The 30 day free trial edition can be found from the website:

http://www.techsmith.com/download/camtasia/
} 
than ten minute duration are more appropriate and video clips with too long duration may make them confused, which is consistent with the findings by the existing literature [6]. They also noted that video clips help them being able to talk with group members and finish the project after the class. Further valuable comments made by students include that it is better to have a variety of formats for them to download video clips and then they about watch video clips on different devices such as a large screen, an iPod, and an Ipad.

\section{Conclusion}

This initial exploration into the use of video clips to enhance accounting students' learning experiences in accounting information systems class can be seen as successful, although there are several operational difficulties to be resolved in the future. The use of the video clips has expanded the range of ways that accounting teachers disseminate knowledge to accounting students. This has enabled accounting students to learn accounting information systems by a multi-layered learning approach, which includes a combination of traditional lectures and video clips. We hope to continue this exploration with other cohorts of students in the future.

\section{REFERENCES}

[1] R. E. Mayer, “Multimedia Learning,” In: B. H. Ross, Ed., The Psychology of Learning and Motivation, Vol.41, Academic Press, San Diego, 2002, pp. 85-139.
[2] M. Mckinnon, "Teaching Technologies: Teaching English Using Video,”.

http://www.onestopenglish.com/support/methodology/tea ching-technologies/teaching-technologies-teaching-englis h-using-video/146527.article

[3] W. Smith, R. Rafeek, S. Marchan and A. Paryag, "The Use of Video-Clips as a Teaching Aide” European Journal of Dental Education, Vol. 16, No. 2, 2012, pp. 91-96. http://dx.doi.org/10.1111/j.1600-0579.2011.00724.x

[4] J. Lance and P. Kitchin, "Promoting the Individual Learning Styles of Masters Students Studying Marketing-related Modules through the Use of YouTube VideoClips," Investigations in University Teaching and Learning, Vol. 4, No. 2, 2007, pp. 111-125.

[5] M. Holtzblatta and N. Tschakertb, "Expanding Your Accounting Classroom with Digital Video Technology" Journal of Accounting Education, Vol. 29, No. 2-3, 2011, pp. 100-121.

[6] A. Chan and M. J. W. Lee, “An MP3 a Day Keeps the Worries Away: Exploring the Use of Podcasting to Address Preconceptions and Alleviate Pre-class Anxiety amongst Undergraduate Information Technology Students,” In: D. H. R. Spennemann and L. Burr, Eds., Good Practice in Practice: Proceedings of the Student Experience Conference, Wagga Wagga, 2005, pp.58-70. 